\title{
Eksklusi Spasial di Era Demokratisasi: Politik Ruang dan Zonasi Kawasan di Selayar
}

\section{Slamet Riadi}

Department Antropologi, Fakultas Ilmu Budaya, Universitas Gadjah Mada.

Email Coresponden: tariansajak@gmail.com

\begin{tabular}{l}
\hline ARTICLE INFO \\
\hline Keywords: \\
Developments Area; \\
Politics of Space; Spatial \\
Exclusion; Kampung Bau. \\
\\
How to cite: \\
Riadi, S. (2019). EKsklusi \\
Spasial di Era \\
Demokratisasi: Politik \\
Ruang dan Zonasi \\
Kawasan di Desa \\
Bontosunggu Kabupaten \\
Selayar. ETNOSIA: Jurnal \\
Etnografi Indonesia. 4(1): \\
20 - 40. \\
DOI: \\
10.31947/etnosia.v4i1.6170
\end{tabular}

\begin{abstract}
This research aims to know how the politics of space and developments area in Bontosunggu, has correlation with rural democratization's discourse, especially in rural development planning. Some years ago, Bontosunggu had so many developments area program, such as building transportation infrastructure (Bandara) and rural economy development in west coastal area from this village. Some of this program namely KEK (Kawasan Ekonomi Khusus), PISEW (Pengembangan Infrastruktur Sosial-Ekonomi Wilayah). This study was conducted in Bontosunggu, Selayar in November 2018 until January 2019. Data was collected using indepth interview, observation, and photograph interview. The participants in this research, consist of rural government, society in Kampung Bau, and policy government of Kabupaten Kepulauan Selayar (BAPPEDA and Dinas Pemerintahan Desa). The research finding indicates: Firstly, process of planning developments (KEK and PISEW) area in Bontosunggu has an impact on rural development orientations. Secondly, the politics of space in Bontosunggu has made a process of spatial exclusion to Kampung Bau. Thirdly, process of spatial exclusion to Kampung Bau, has correlated to the legitimation and regulation's mechanism, then also with the development area and rural democratization's process.
\end{abstract}

Copyright (C) 2019 ETNOSIA. All rights reserved.

\section{Pendahuluan}

Akhir tahun 2018, Desa Bontosunggu berhasil keluar sebagai pemenang lomba desa tingkat kabupaten juga berhak untuk maju sebagai perwakilan dari Kabupaten Kepulauan Selayar dalam perlombaan desa tingkat provinsi. Terpilihnya desa ini sebagai representasi 'desa terbaik' di Kabupaten Kepulauan Selayar, disebabkan karena laju pembangunan infrastruktur yang 
massif, serta kelengkapan prasarana pelayanan umumnya. Dari segi pelayanan transportasi, desa ini memiliki bandara, terminal, dan dermaga, sedangkan dalam aspek pelayanan umum, juga memiliki dua sekolah (SD dan SMP) serta puskesmas desa yang terbilang cukup maju.

Akses menuju ke Desa Bontosunggu, dapat ditempuh dengan melalui dua jalur, yakni jalur darat maupun udara. Melalui jalur darat, setelah sampai di pelabuhan Pamatata di ujung utara kabupaten ini, perjalanan kembali dilanjutkan ke selatan, dengan waktu tempuh sekitar satu jam lebih. Sedangkan jika melalui jalur udara, perjalanan dari Bandara Sultan Hasanuddin di Makassar menuju ke Bandara H. Aeropala di Selayar, dapat ditempuh kurang lebih 30 menit lamanya dan lansung tiba di Desa ini.

Jika dilihat dengan menggunakan citra satelit (lihat Gambar 1), nampak terlihat topografi dan bentang alam Desa Bontosunggu yang beragam, sebab di desa ini, terdapat beberapa sumber daya alam yang diolah oleh masyarakat setempat dan juga masyarakat yang tinggal di luar desa, diantaranya ialah tambak ikan dan udang (empang), tambak garam, lahan pertanian, dan juga kawasan lautnya.

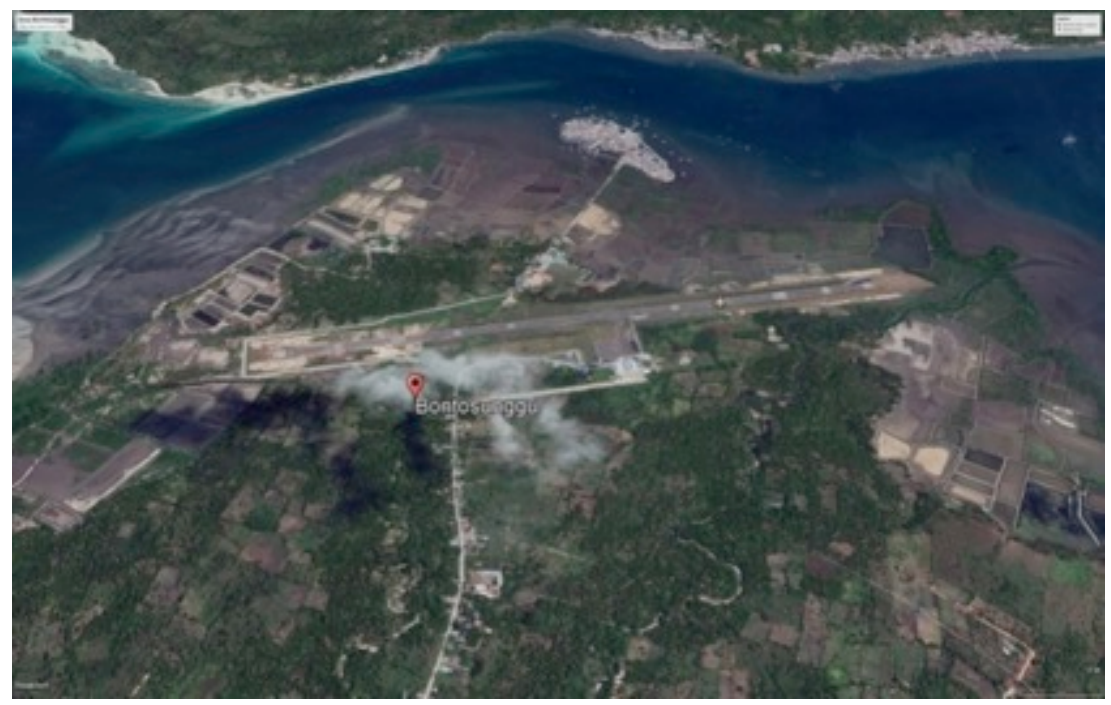

Gambar 1. Topografi Bentang Alam Desa Bontosunggu, Sumber: Diolah melalui aplikasi google earth

Keragaman bentang alam desa dengan lima dusun ${ }^{1}$ di dalamnya ini, ternyata menyimpan rentetan peristiwa kemajuan disatu sisi, namun ketimpangan pada sisi yang lain, akibat dari masuknya beragam program pembangunan kawasan

\footnotetext{
${ }^{1}$ Dusun tersebut antara lain, Dusun Galung sebagai dusun pertama di sebelah timur desa dengan mata pencaharian warganya mayoritas sebagai petani. Selanjutnya ialah Dusun Bontomanai, terletak di tengah desa setelah melewati landasan pacu bandara. Di dusun ini mayoritas warganya juga bekerja sebagai petani. Sedangkan tiga dusun lainnya yakni Padang Utara, Padang Tengah, dan Padang Selatan, terletak di perkampungan nelayan Padang. Dimana mayoritas warganya bekerja sebagai nelayan.
} 
di desa ini. Beberapa program pembangunan 'zonasi' kawasan yang ada di desa ini antara lain meliputi program Pengembangan Kawasan Bandara (RTRW Kabupaten Kepulauan Selayar), program Pengembangan Infrastruktur Sosial-Ekonomi Wilayah (PISEW), dan penggodokan pengembangan Kawasan Ekonomi Khusus (KEK) Pariwisata.

Di Dusun Padang tengah sebagai lokasi pengembangan kawasan ekonomi dan transportasi, terfokus pada revitalisasi tiga infrastruktur pendukung laju ekonomi dan transportasi desa, yakni pasar, terminal, dan dermaga desa. Ketiga infrastruktur pendukung di pesisir barat desa ini, terletak pada posisi yang strategis dan penting. Sebab di lokasi inilah yang masyarakat berkumpul, berjualan hasil laut maupun kebun, dan juga sebagai tempat penyebarangan menuju ke Pulau Pasi².

Konsentrasi pembangunan desa yang terfokus di perkampungan nelayan Padang, seperti yang saya bahasakan, dikonfirmasi oleh Suratman, selaku Kepala Desa Bontosunggu, bahwa Padang merupakan pusat desa, sebagaimana yang diutarakan kepada saya bahwa:

Memang ini Padang pusatnya desa, jadi beberapa pembangunan di desa fokus disini. Karena disini mi juga ada pasarnya, terminal, sama dermaga. Dulu di Padang ini dimasuki air, tapi sekarang Alhamdulillah sudah dikasih tinggimi jalanan. Sudah mi juga ditambai timbunan di sebelah barat itu. Karena dulu itu, pinggiran tanggul sebelah barat di warung kopi BumDes, tapi sudah mi ditambahi, dibuatmi juga terminal, makanya tambah luas dan jadi mi aset desa di bagian sana (Suratman, 23 November 2018).

Tidak hanya dilegitmasi sebagai pusat desa, pembangunan yang terkosentrasi di Padang juga dilegitmasi oleh nilai historis (Spatial Histories) dari kampung ini, sebagai pusat kota Selayar di masa lalu, ujar Pak Bahrudding, Kepala Dusun Padang Utara, kepada saya:

Ada banyak suku di desa ini, khususnya di Padang, ada bajo, bugis, melayu (ince), tiongkok (ance dan baba), karena dulunya, sekitaran tahun 1960-1970an, di Padang ini jadi pusat kotanya selayar dan sekaligus sebagai pusat perekonomian. Kalau sejarahnya, dulu orang pertama datang disini itu orang Bajo, niatnya hanya untuk berlindung dari kerasnya ombak. Nah, pada saat yang sama datang sekelompok suku Bugis yang ingin membeli ikan dan menjual beras, datang pula orang selayar pedalaman yang menjual sayur, akhirnya lambat laun berkembanglah wilayah ini sebagai pusat perekonomian di desa (Pak Bahrudding, 23 November 2018).

Sedangkan di Dusun Bontomanai, sebagai pusat pembangunan kawasan bandara H. Aeropala pada tahun 1997, memberi cerita yang sedikit berbeda dari kehadiran bandara di kabupaten ini. Dibalik kisah kemudahan akses

2 Di Pulau Pasi ini terdapat tiga desa, yakni Desa Bontoborusu, Desa Kahu-Kahu, dan Desa Bontolebang, yang semuanya menggunakan akses dermaga Padang, jika ingin menyeberang ke daratan utama Kepulauan Selayar. 
masyarakat mengunjungi ataupun keluar dari kabupaten ini, ternyata menyimpan cerita tentang tergadainya ruang hidup (lahan) masyarakat yang menggantungkan hidupnya sebagai petani. Selain ruang hidup yang dirampas lalu diubah menjadi sebuah landasan bandara, pemukiman mereka pun direlokasi ke sebuah perkampungan baru di sebelah selatan desa, bernama Kampung Bau (baru).

Memasuki pemukiman baru di ujung selatan desa, lilitan kabel di pepohonan dan jalan yang masih berbatu (lihat Gambar 2), menjadi pembandangan yang dijumpai sejauh 600 meter sebelum tiba di 22 rumah yang ada di kampung ini. Di kampung tersebut, saya pertamakali berjumpa dengan Pak Jamal, seorang nelayan yang dulunya sebagai petani ${ }^{3}$, bercerita kepada saya terkait kehidupannya di Kampung Bau bahwa:

Kalau malam disini pak, sunyi sekali. Ada ji listrik masuk, tetapi terbatas karena sambungan semuaji, yang jelasnya ada cahaya untuk anak-anak disini, kalau kita orangtua, tidak masalahji. Tapi ada juga tidak pake listrik, dia pake lampu senter. Sebenarnya, kita disini tunggu pak desa, kasih masuk listrik dan bantuan air, karena air diambil di galung, itupun biasa tidak jalan air disana. Jadi kalau tidak jalan air, jauh sekaliki ke tana bau ambil air. Pak desa disini masuk, jarang-jarang, itupi na masuk kalau ada maunya (Pak Jamal, 28 November 2018).

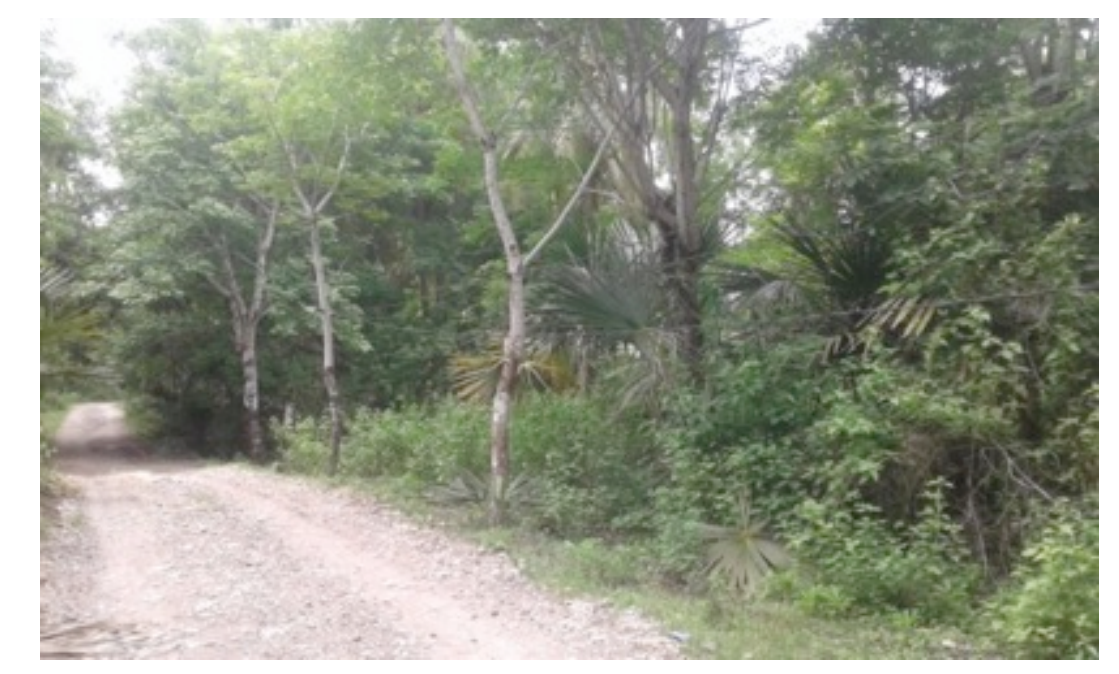

Gambar 2. Jalan Masuk Kampung Bau (Baru) dan Bentang Kabel Listrik di Pohon Sumber: Dokumentasi Pribadi (2019)

Kondisi hidup yang berbeda antara perkampungan nelayan Padang dan Kampung Bau ialah dampak dari masuknya berbagai macam intervensi pembangunan di luar dari kewenangan desa, seperti yang saya maksudkan, sebagai sebuah proyek pembangunan 'zonasi' kawasan. Berdasar pada kondisi yang saya temui dilapangan, maka artikel ini akan lebih fokus untuk bercerita

\footnotetext{
3 Pak Jamal dulunya merupakan salah satu petani yang memiliki lahan produktif yang kini telah disulap menjadi landasan pacu bandara.
} 
terkait soal politik pembangunan infrastruktur dengan tema utama menyangkut soal politik ruang.

Diskursus topik penelitian terkait politik ruang dalam beberapa tiga tahun terakhir, mendapatkan perhatian yang besar dari para kalangan akademisi. Sebut saja misalnya, penelitian yang dilakukan oleh Warda, Andersonb, Gilbertzc, (2017) di kawasan sungai Yellowstone, menunjukkan bahwa program Integrated Water Resource Management (IWRM) merupakan salah satu bentuk pengintegrasian sumber daya dalam suatu kawasan yang bercorak 'neoliberalism governmentality'. Dimana diskursus terkait lingkungan diproduksi baik secara mental dan material, melalui praktik politik pengetahuan yang lebih berorientasi terhadap ekonomi ketimbang persoalan lingkungan.

Selain persoalan integrasi kawasan, isu politik ruang juga sangat erat kaitannya dengan praktik relasi kuasa. Purwani (2017) dalam penelitiannya menunjukkan bahwa terdapat bentuk ideologi senyap, corak hierarkis, dan relasi kuasa dalam pengelolaan tata kelola ruang oleh Kesultanan Yogyakarta dan Surakarta. Lebih jauh lagi, penelitian yang dilakukan oleh Purwani (2017), telah menunjukkan bahwa persoalan dominasi dan kuasa, tidak hanya terjadi dalam praktikpraktik penguasaan individu atau kelompok, melainkan juga dapat mewujud dalam bentuk tata kelola ruang.

Selain Purwani (2017), pemanfaatan ruang sebagai arena produksi kekuasaan, juga ditemukan dalam studi yang dilakukan oleh Benjamin Rubbers (2019). Dalam penelitiannya, Rubbers (2019) mengungkapkan bahwa secara periodik, kawasan perumahan untuk para pekerja tambang di Conglese copperbelt, digunakan sebagai arena teknologisasi ruang (kuasa) untuk mengontrol dan sekaligus mendisiplinkan para pekerja tambang yang ada di kawasan tersebut.

Beberapa penelitian di atas, belum ada yang menyentuh terkait persoalan politik pembangunan infrastruktur yang disandingkan dengan dua proses secara bersamaan terjadi di suatu kawasan pedesaan, khususnya Indonesia, yakni persoalan pengembangan 'zonasi' kawasan dan 'demokratisasi' pedesaan. Olehnya itu, artikel ini akan mengisi kekosongan tersebut, sebagai upaya memahami lebih jauh, terkait proses politik pembangunan infrastruktur di tengah wacana zonasi kawasan dan proses demokratisasi di Bontosunggu.

\section{Metode Penelitian}

Penelitian ini berlokasi di desa Bontosunggu, Kecamatan Bontoharu, Kabupaten Kepulauan Selayar. Di desa ini, masyarakatnya memiliki beragam aktivitas penunjang ekonomi domestiknya masing-masing, ada yang bekerja sebagai petani tambak ikan dan garam, berkebun, nelayan, dan bahkan ada beberapa warga yang mengerjakan aktivitasnya di darat dan juga di laut. 
Secara geografis, desa ini memiliki keunikan dan keberagaman sumber daya alamnya. Hal ini terlihat dari beragamnya aktivitas ekonomi masyarakatnya yang secara garis besar bermatapencaharian di darat maupun di laut. Tidak hanya keberagaman sumber daya alamnya, dari segi infrastruktur, desa ini juga memiliki bandara, terminal, pasar desa, puskesmas, dan dermaga penyeberangan.

Secara keseluruhan penelitian ini berlansung mulai dari tanggal 21 November 2018 sampai pada tanggal 22 Januari 2019. Pertama kali mengunjungi desa ini, saya memulai dengan mengelilingi jalan raya desa, dimulai dari dusun Galung, memutari landasan pacu bandara, memasuki dusun Bontomanai, mengelilingi perkampungan Padang, dan kembali ke kantor desa, untuk bertemu dengan kepala desa atau aparatur desa saat itu. Sesampainya di kantor desa, saya kemudian mengutarakan maksud penelitian saya kepada kepala desa, dengan memberikan surat keterangan penelitian dari Universitas Gadjah Mada, yang saya urus sebelum saya ke lokasi penelitian.

Setelah mengurus ijin penelitian di desa dan sekaligus mengutarakan niat saya untuk tinggal dan melakukan penelitian di desa ini, maka agenda selanjutnya ialah menyusun beberapa kegiatan penelitian dan daftar informan yang akan saya wawancarai. Sebelum menyusun daftar informan, saya menyusun beberapa agenda atau fokus penelitian di tiap minggunya, yang berlansung secara fleksibel, namun tetap memiliki visi yang ingin dicapai pada tiap pekannya.

Berdasar pada beberapa agenda penelitian di atas, maka langkah selanjutnya ialah membuat klasifikasi dan daftar informan yang akan saya wawancarai di lapangan, serta menyesuaikan dengan fokus penelitian yang telah saya tentukan di minggu kedua saya berada di lapangan. Adapun beberapa klasifikasi informan yang saya wawancarai terdiri dari pemerintah desa, kepala dusun, tokoh masyarakat, masyarakat kampung bau, dan pemerintah daerah. Nama-nama yang digunakan dibawah ini ialah nama samaran, guna untuk menjaga kerahasiaan informan dan juga data yang telah disampaikan. Berikut nama-nama informan yang terlibat dalam penelitian ini (lihat Tabel 1):

\begin{tabular}{clcll}
\hline & \multicolumn{4}{c}{ Tabel 1. Informan Penelitian } \\
\hline No & \multicolumn{1}{c}{ Nama } & $\begin{array}{c}\text { Usia } \\
\text { (tahun) }\end{array}$ & \multicolumn{1}{c}{ Pekerjaan } & $\begin{array}{c}\text { Status } \\
\text { Kependudukan }\end{array}$ \\
\hline 1. & Pak Suratman & 62 & Kepala Desa Bontosunggu & Padang Tengah \\
\hline 2. & Pak Bahrudding & 48 & Kepala Dusun & Padang Utara \\
\hline 3. & Pak Budi & 51 & Kepala Dusun & Bontomanai \\
\hline 4. & Pak Anto & 45 & Petani & Kampung Bau \\
\hline 5. & Pak Hanafi & 32 & Ketua BPD Bontosunggu & Kampung Bau \\
\hline 6. & Pak Aslam & 58 & Nelayan & Kampung Bau \\
\hline
\end{tabular}




\begin{tabular}{cllll}
\hline 7. & Pak Jamal & 33 & Nelayan & Kampung Bau \\
\hline 8. & Pak Ibrahim & 43 & Petani & Kampung Bau \\
\hline 9. & Ibu Ati & 40 & IRT & Kampung Bau \\
\hline 10. & Ibu Sinar & 39 & IRT & Kampung Bau \\
\hline 11. & Pak Rianto & 40 & Pegawai BAPPEDA & Benteng \\
\hline 12. & Pak Anas & 37 & Pegawai Pemerintahan Desa & Benteng \\
\hline 13. & Ibu Nurjannah & 47 & Pegawai Pemerintahan Desa & Benteng \\
\hline
\end{tabular}

Penelitian ini menggunakan dua jenis data, yakni data primer dan sekunder. Data primer diperoleh melalui metode partisipasi-observasi dan wawancara mendalam. Metode partisipasi-observasi dilakukan untuk memeroleh data yang berkaitan dengan perencanaan, fokus, serta arah pembangunan desa, aktivitas sosio-spasial masyarakat, aktivitas jalan raya desa, rapat pertanggungjawaban dan musrembang desa. Sedangkan metode wawancara mendalam ditempuh dengan dua cara, yakni wawancara menggunakan foto (spesifik foto pembangunan, jalan, dan peta desa) dan wawancara semiinformal (tidak kaku, dinamis, dan eksploratif). Metode ini digunakan untuk menghasilkan data berupa sejarah dan politik lokal desa, pengalaman bermusrembang, dan soal ketimpangan pembangunan serta eksklusi sosiospasial masyarakat Kampung Bau.

Data sekunder didapatkan melalui penelusuran arsip di kantor desa, BAPPEDA, PU, dan Dinas Pemerintahan Desa Kabupaten Kepulauan Selayar, yang secara spesifik berhubungan dengan perencanaan pembangunan desa, Rancangan Tata Ruang dan Wilayah (RTRW), Rancangan Kawasan Ekonomi Khusus (KEK) Pariwisata. Selain penelusuran arsip, saya juga melakukan beberapa pencarian data di media sosial (facebook, instagram, dan youtube) dengan memasukkan kata kunci desa bontosunggu selayar, guna untuk melihat aktivitas maupun perkembangan desa Bontosunggu yang dicitrakan melalui jejaring media sosial.

\section{Hasil Penelitian dan Pembahasan}

\section{- Politik Ruang dan Pengembangan Kawasan}

Beberapa tahun terakhir diberbagai saluran informasi, sering terdengar istilah tentang kebijakan satu peta, integrasi kawasan, pembangunan tematik, konservasi, dan zonasi wilayah. Istilah-istilah tersebut berkaitan erat atau paling tidak memiliki hubungan intim dengan perkembangan logika Negara di lain sisi, serta logika kapital di sisi yang lain. Hubungan mesra yang terbangun dalam dua logika tadi, bertemu dalam suatu proyek pembangunan pada ruang-ruang geografis tertentu. Perencanaan pembangunan dalam suatu ruang, diajukan dan ditetapkan melalui dua pertimbangan penting yakni mempertemukan 
kepentingan pasar dan kepentingan politik, ujar ahli geografi dan ekonomi politik, David Harvey (2003: 124).

Di Desa Bontosunggu, kehadiran Bandara H. Aeropala sebagai bentuk proyek pembangunan infrastruktur transportasi, menjadi bukti nyata dari pertemuan antara dua logika yang dibahasakan Harvey (2003). Pembangunan yang mulai digodok pada tahun 1997 ini, menjadi sebuah awal dari titik krisis bagi masyarakat yang menggantungkan hidupnya sebagai petani di Bontosunggu. Hal ini dikarenakan adanya pengalihan fungsian lahan, semula digunakan untuk berkebun, kini disulap menjadi landasan pacu sebuah bandara. Terjadinya konversi lahan produktif petani menjadi pengembangan kawasan bandara, sebagaimana yang terjadi di Desa Bontosunggu, persis yang dibahasakan oleh Eko Cahyono $(2017 ; 377)$, tim pengajar di Fakultas Ekologi Manusia Institut Pertanian Bogor (IPB), sebagai sebuah kondisi yang akan menimbulkan konflik sekaligus krisis di kawasan pedesaan, berupa;

De-Peasanisasi, ialah beragam bentuk kondisi yang menunjukkan terlemparnya kelompok petani dari dunia pertaniannya. De-Ruralisasi, ialah beragam bentuk kondisi yang menunjukkan terlemparnya masyarakat desa dari desanya sendiri. De-Agranisasi, ialah beragam bentuk kondisi yang menunjukkan krisis dan kerusakan sumber-sumber agrarian akibat dari ekspansi kapital dan industri ekstraktif di pedesaan secara massif dan meluas (Cahyono, 2017; 378).

Kehadiran bandara di Bontosunggu, disatu sisi mempercepat akses masyarakat Selayar ke Makassar, namun disisi yang lain berdampak buruk pada mata pencaharian petani. Hal ini disebabkan karena proyek pembangunan tersebut telah menghilangkan sumber (lahan) produktif bagi petani (De-Peanisasi) dan sekaligus merusak aliran sungai yang berujung pada kegagalan panen para petani tambak (De-Agranisasi) di Desa Bontosunggu. Kehilangan lahan produktif petani di desa ini, dituturkan oleh Pak Salam, aparatur desa di masa pembangunan Bandara $H$. Aeropala, ketika saya mengunjungi rumahnya,

Tapi itu perluasan bandara kalau mauki bicara dampak negatifnya, juga banyak. Karena banyak lahan pertanian yang dihilangkan. Makanya, seharusnya pemerintah mencarikan pekerjaan untuk orang-orang yang diambil tanahnya jadi lokasi bandara. Tapi tidak, itumi sekarang banyak warga yang dulu punya kebun, sekarang alih profesi jadi tukang batu. Padahal, tradisi berkebun disini; bertani itu menanam kelapa untuk masa tua, sekarang tidak begitumi. Tidak adami lahan (Pak Salam, 9 Desember 2018).

Selain kehilangan lahan untuk berkebun, implikasi dari pembangunan bandara di desa ini, juga merusak sistem ekologis, berupa aliran sungai yang diubah mengikuti landasan pacu bandara. Kerusakan aliran sungai di tengah-tengah desa ini, berdampak pada kerusakan beberapa tambak di sebelah timur bandara, seperti yang diujarkan oleh Pak Hanafi, Ketua Badan Permusyawaratan Desa (BPD) Bontosunggu bahwa; 
Empang yang ditimur bandara itu kalau banjir na masuki air, karena memang dulu waktu dikerja itu aliran sungai yang na ubah Bandara tidak terlalu dalam, apalagi dekat pantai disitu, kalau pasang air laut na bawa lagi masuk pasir, jadi susah i (Pak Hanafi, 17 Desember 2018).

Bagi masyarakat korban relokasi bandara, yang kini bermukim di perkampungan baru (kampung bau), kehadiran bandara telah mengubah sebagian besar hidup mereka, utamanya terkait soal mata pencaharian. Kondisi tersebut dikisahkan oleh Pak Aslam, warga kampung bau yang bekerja sebagai nelayan, kepada saya ketika mengunjungi rumahnya yang terletak 800 meter dari jalan utama desa bahwa:

Dulu waktu masih di bandara, ramai sekaliki karena lansung ki tembus dengan Galung juga, kebun juga lumayan. Saya dulu sampai 1 hektar saya urus kebun. Ada saya Tanami jagung, pisang, kacang tanah, sama sayur-sayur. Tapi pas mau na beli tanahnya orang di Padang dan dijadikan bandara sama pemerintah. Tidak adami, terpaksa kesini semua maki lagi tinggal. Lisrtrik disini disambung di kampung camba' semua (Pak Aslam, 30 November 2018).

Pembangunan kawasan bandara H. Aeropala yang massif dalam beberapa tahun terakhir, dipengaruhi oleh penggodokan Kabupaten Kepulauan Selayar menjadi salah satu Kawasan Ekonomi Khusus (KEK) dalam bidang pariwisata (lihat Gambar 3). Sebagaimana visi dan program strategis dari pemerintah pusat, KEK Indonesia ialah kawasan dengan batasan tertentu yang memiliki keunggulan geoekonomi dan geostrategis wilayah serta diberikan fasilitas dan insentif khusus sebagai daya tarik investasi. Sampai hari ini, terdapat 12 wilayah yang terintegrasi dalam KEK ini, empat untuk sektor wisata dan delapan untuk sektor industri (lihat Gambar 4).

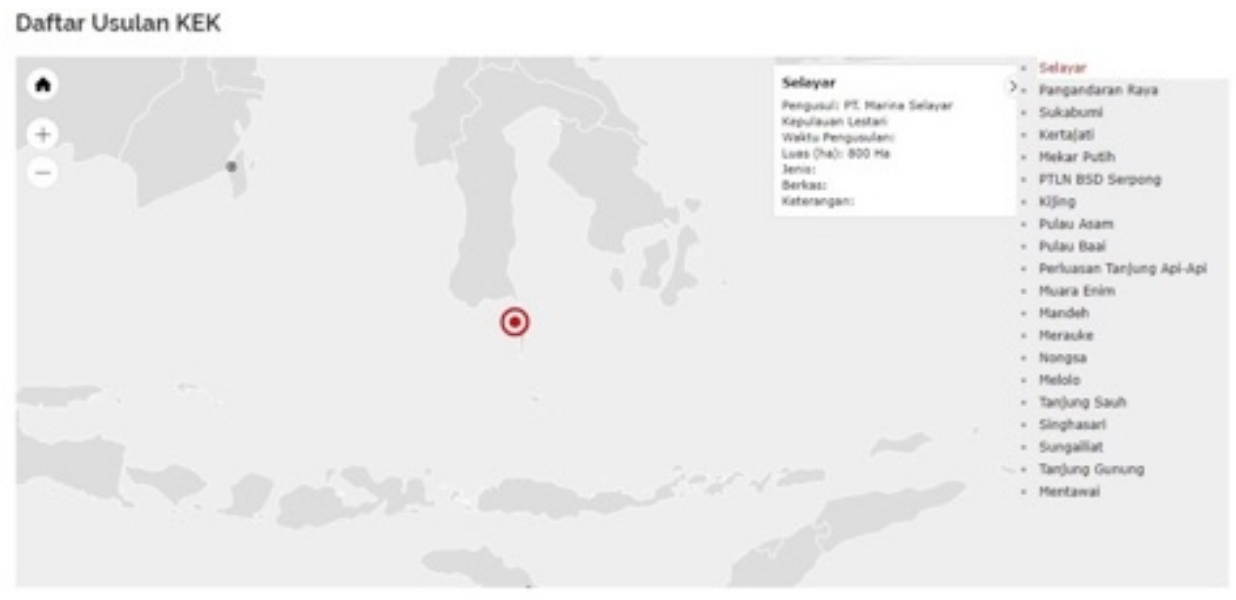

Gambar 3. Selayar sebagai kawasan yang masuk daftar usulan KEK Sumber: http://kek.go.id/usulan-kek (2019)

Pengembangan Selayar menuju KEK Pariwisata, memiliki pengaruh yang signifikan dalam agenda pembangunan di Desa Bontosunggu. Kondisi tesebut dipicu oleh faktor bahwa bandara yang terletak di tengah desa ini, ialah sebagai unsur penting dalam sektor pengembangan pariwisata, sebab berfungsi untuk 
mempercepat laju perpindahan manusia dari satu tempat ke tempat yang lain. Oleh sebab itu, kawasan Desa Bontosunggu dalam agenda perencanaan pembanguanan KEK Pariwisata Selayar, juga masuk dalam zonasi wilayah yang diperuntukkan untuk pengembangan infrastruktur transportasi. Masuknya Bontosunggu dalam perencanaan area KEK Selayar, dituturkan oleh Pak Rianto, selaku kepala seksi fisik dan prasarana Bappeda, kepada saya, sewaktu mengunjungi kantornya;

Itu Desa Bontosunggu, dalam revisi RTRW yang terbaru, dia sudah masuk salah satu kawasan KEK, karena disana ada bandara dan transportasi lautnya yang menyambungkan antara pulau selayar besar dengan pulau pasi yang jadi pusat kawasan wisata disana. Jadi strategiski, istilahnya desa Bontosunggu itu jadi penyangga desa-desa yang ada di sekitarnya, khususnya bidang transportasi (Pak Rianto, 8 Januari 2019).

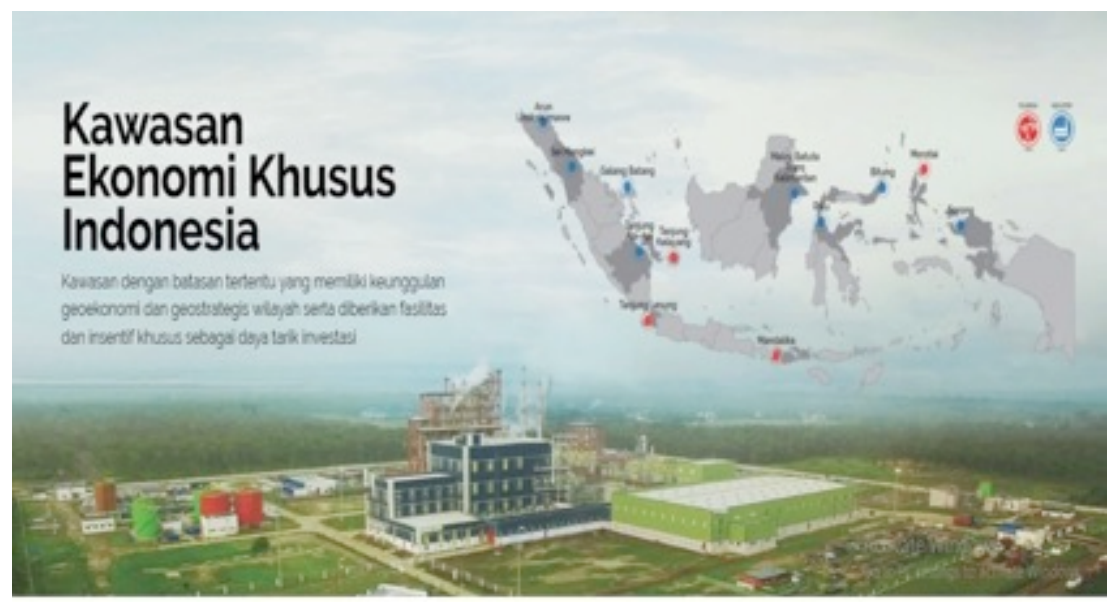

Gambar 4. Persebaran 12 KEK Indonesia Sumber: http://kek.go.id/ (2019)

Penuturan Pak Rianto tersebut mengindikasikan bahwa corak pembangunan di Desa Bontosunggu, mesti menyesuaikan dengan skema tata ruang yang diperuntukan untuk pengembangan infrastruktur transportasi, khususnya dalam hal pembangunan kawasan bandara. Implikasi dari KEK Selayar dan kehadiran bandara di Bontosunggu, mewujud kedalam sebuah logika keruangan, bertajuk ekspansi kapital pada ruang geografis di pedesaan. Bergeraknya arus kapital dalam bentuk program pengembangan kawasan bandara, berada pada arus sirkut sekunder4, dalam bahasa Harvey (2003; 109) sebagai sebuah produksi dan konsumsi tetap yang termanifestasikan dalam pembangunan infrastruktur penunjang, semisal gedung, jembatan, dan jalan.

\footnotetext{
4 Harvey membagi pergerakan sebuah kapital ke dalam tiga sirkuit, yakni sirkut primer, berhubungan dengan produksi dan konsumsi lansung, sirkuit sekunder, berhubungan dengan produksi dan konsumsi tetap yang termanifestasikan dalam pembangunan infrastruktur penunjang, semisal gedung, jembatan, dan jalan, sedangkan sirkuit tersier, mewujud dalam bentuk pengembangan sumber daya manusia, penelitian, dan belanja-belanja sosial (Harvey, 2003: 108-111).
} 
Masuknya kawasan Bontosunggu dalam pembangunan zonasi KEK, berimplikasi mengubah dan memengaruhi gerak pembangunan di tingkat desa. Jika di tarik ke dalam skala yang lebih luas lagi, kondisi tersebut juga memiliki dampak yang lain, yakni masuknya berbagai intervensi pembangunan kawasan di desa. Salah satu program yang masuk di Bontosunggu selain pengembangan Zonasi KEK ialah Program Pengembangan Infrastruktur Sosial-Ekonomi Wilayah (PISEW) di tahun 2018. Dalam program ini, Bontosunggu menjadi salah satu desa yang berstatus kawasan penyangga terkhusus dalam bidang transportasi (lihat Gambar 5).

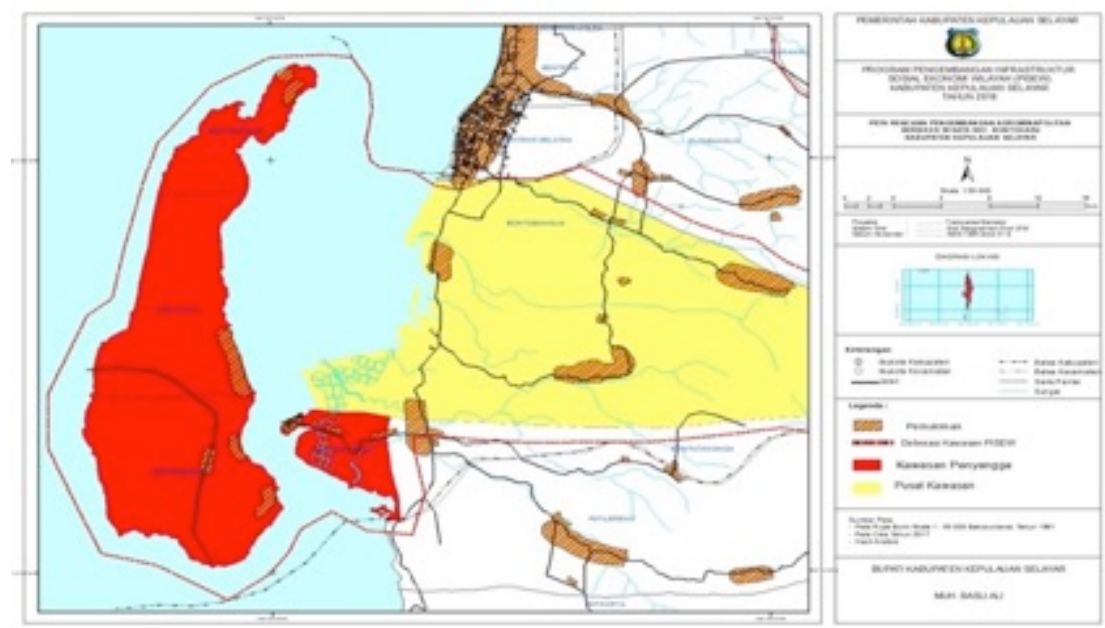

Gambar 5. Lokasi Kawasan Program PISEW di Kecamatan Bontoharu Sumber: Dokumentasi BAPPEDA (2019)

Dalam dokumen rencana program PISEW (2017;5) untuk perencanaan anggaran tahun 2018. Desa Bontosunggu masuk ke dalam salah satu alternatif pengembangan agromonopolitan berbasis wisata di kecamatan Bontoharu, bersama dengan Desa Bonntolebang, Kahu-Kahu, dan Bontoborusu sebagai kawasan penyangga (berwarna merah), serta Kelurahan Bontobangun sebagai pusat kawasan (berwarna kuning). Dilirik dari aspek geografis, tiga desa (Bontolebang, Kahu-Kahu, Bontoborusu) yang masuk dalam kawasan penyangga program pengembangan kawasan agromonopolitan berbasis wisata, terletak di Pulau Pasi yang bersebelahan dengan Desa Bontosunggu. Tidak hanya berdekatan secara geografis, akses menuju ke tiga desa yang berada di Pulau Pasi, juga ditempuh dengan menggunakan ojek laut, dengan waktu tempu kurang dari 10 menit, yang terdapat di dermaga perkampungan nelayan Padang, Desa Bontosunggu (lihat Gambar 6). 


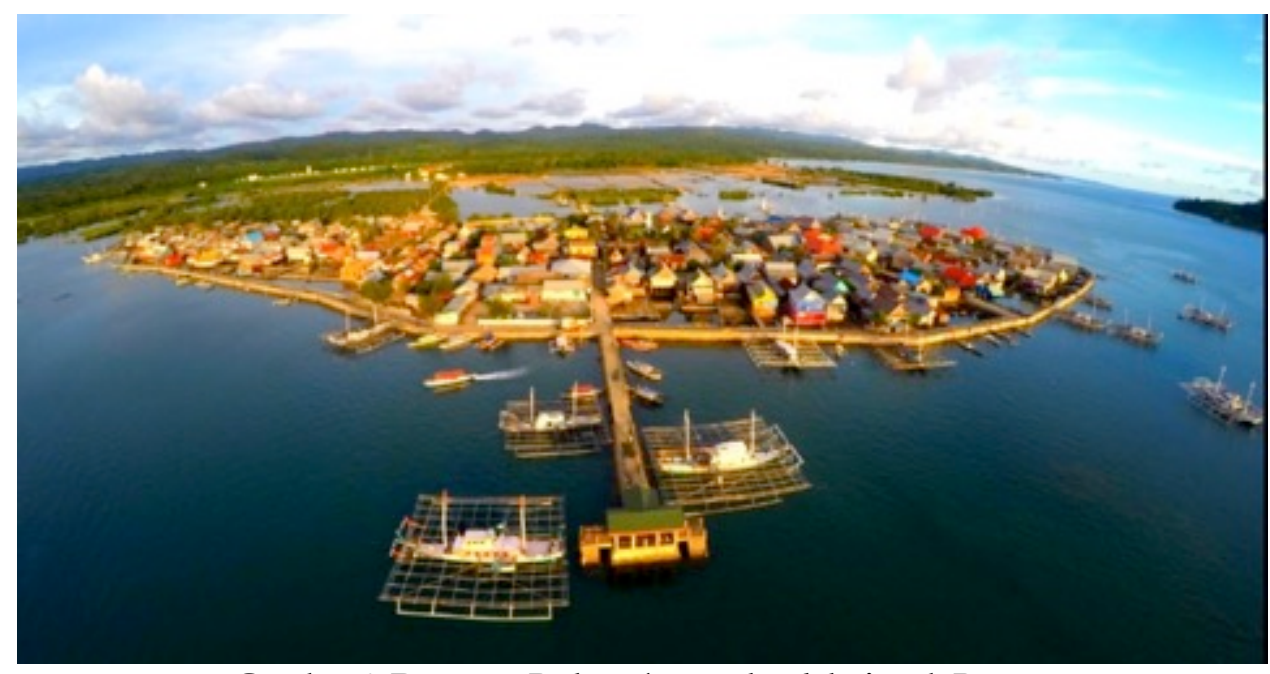

Gambar 6. Dermaga Padang 'pusat desa' dari arah Barat Sumber: Dokumentasi BAPPEDA (2019)

Status Desa Bontosunggu yang masuk ke dalam program PISEW, juga dikonfirmasi lansung oleh Pak Anas, selaku Kepala Seksi Keuangan dan Aset Desa, ketika saya mengunjungi kantornya yang terletak di pusat kabupaten, Benteng. Ketika masuk ke ruangan Pak Anas dan menjelaskan maksud dari kedatangan saya, dia kemudian mempersilahkan saya duduk dan mulai bercerita terkait keterkaitan Desa Bontosunggu dengan program PISEW, seperti yang disampaikannya kepada saya bahwa;

Itu desa Bontosunggu, menjadi salah satu desa yang menjadi prioritas program PISEW khusus untuk bagian pengembangan perikanan sama transportasi. Dananya ini lansung dari pusat. Jadi Desa Bontosunggu itu dalam agenda pembangunannya harus menyesuaikan dengan pengembangan perikanan dan transportasi (Pak Anas, 19 Desember 2018).

Sebagai sebuah kawasan penyangga dalam program PISEW seperti yang diujarkan oleh Pak Anas. Desa Bontosunggu, utamannya perkampungan nelayan Padang, juga masuk ke dalam area Pusat Pelayanan Lingkungan (PPL) untuk wilayah Baloiya, Gusung, dan Dongkalang. Ketiga wilayah tersebut merupakan kawasan wisata di Pulau Pasi, dimana dalam beberapa tahun terakhir menjadi salah satu destinasi yang ramai dikunjungi oleh para wisatawan. Tidak hanya sebagai PPL di tiga area wisata tersebut, perkampungan nelayan Padang juga termasuk dalam salah satu wilayah Kawasan Peruntukan Pariwisata (KPP) sejarah budaya berupa meriam kuno dan jangkar raksasa, dalam program PISEW yang telah saya bahasakan sebelumnya. 
Baik secara geografis maupun keterhubungan wilayah, antara Desa Bontosunggu dengan tiga desa yang ada di Pulau Pasi seperti yang telah saya bahasakan, memberi pengaruh pada pembangunan desa, khususnya di perkampungan Padang. Skema pembangunan Bontosunggu yang mengikuti logika pengembangan kawasan pariwisata di Pulau Pasi, diperjelas oleh Ibu Ismi, selaku Kepala Seksi Pembangunan Desa, yang mengatakan kepada saya bahwa;

Bontosunggu masuk dalam wilayah pendukung pengembangan kawasan perikanan dan pariwisata untuk Desa Bontoborusu dan Bontolebang. Karena akses ke dua desa ini juga harus lewat di Padang. Makanya Bontosunggu juga masuk dalam kawasan pembangunan yang mendukung dua aspek tadi, Perikanan sama Pariwisata (Ibu Ismi, 19 Desember 2018).

Konsekuensi logis dari berbagai program pembangunan kawasan, berbasis pengembangan sarana transportasi bandara, dermaga, maupun pariwisata, memberi pengaruh pada pola distribusi pembangunan yang timpang dan hanya terfokus pada satu atau beberapa ruang geografis di desa Bontosunggu. Ketimpangan pembangunan di Desa Bontosunggu, dinilai oleh beberapa warga sebagai keberpihakan kepala desa, dalam memutuskan rancangan pembanguan di desa, seperti yang disampaikan oleh Ibu Ita, pemilik kios yang ada di Bontomanai; Disini, nda pernah dibangun jalanan. Di Padang itu tiga lapismi. Yahh, karena kepala desanya juga orang Padang (Ibu Ita, 1 Desember 2018).

Selain Ibu Ita, salah satu warga yang bermukim di dusun Galung, Ibu Ida, pemilik kios di jalan poros di dusun tersebut, juga mengutarakan kekecewaannya terhadap pembangunan desa yang hanya fokus di Padang dan rancangan akan dibangunnya jalanan yang menyambungkan antara Padang dan Benteng, melalui jalur laut, sebagaimana yang diujarkannya kepada saya;

Disini desa, di Padang ji itu pembangunan pokoknya. Makanya disini tidak terlalu dianggapmi pak desa. Apalagi periode ketiganya mi ini, terakhirmi juga, tidak bisa mi juga mencalonkan lagi. Itu dulu waktu periode keduanya, seandainya bukan orang didalam (dusun Galung dan Bontomanai) yang kasih menang i, dikalah i. karena suaranya saja di Padang dikalah, na tempat tinggalnya mi itu. Makanya orang-orang disini, seperti kalau di anak tirikan. Iitu seandainya tidak ada lomba desa, tidak ada pi tong sampah untuk rumah-rumah disini. Di padang itu tiga kali mi dapat orang. Oh iya saya dengar-dengar juga, itu nanti ada rancangan pembangunan jalan na lewati laut dari Benteng ke Padang, pokoknya di Padang semua ji itu pembangunan di desa ini (Ibu Ida, 4 November 2018).

Beberapa program pembangunan kawasan yang ada di Desa Bontosunggu, dapat dikatakan terpusat pada satu kawasan, yakni perkampungan nelayan Padang (lihat Bagan 1). Arus pembangunan desa yang lebih diprioritaskan di Padang tersebut, berdampak pada terjadinya ketimpangan pembangunan, 
antara di luar dan di dalam ${ }^{5}$, terkhusus bagi masyarakat yang bermukim di perkampungan sebelah selatan desa, Kampung Bau.

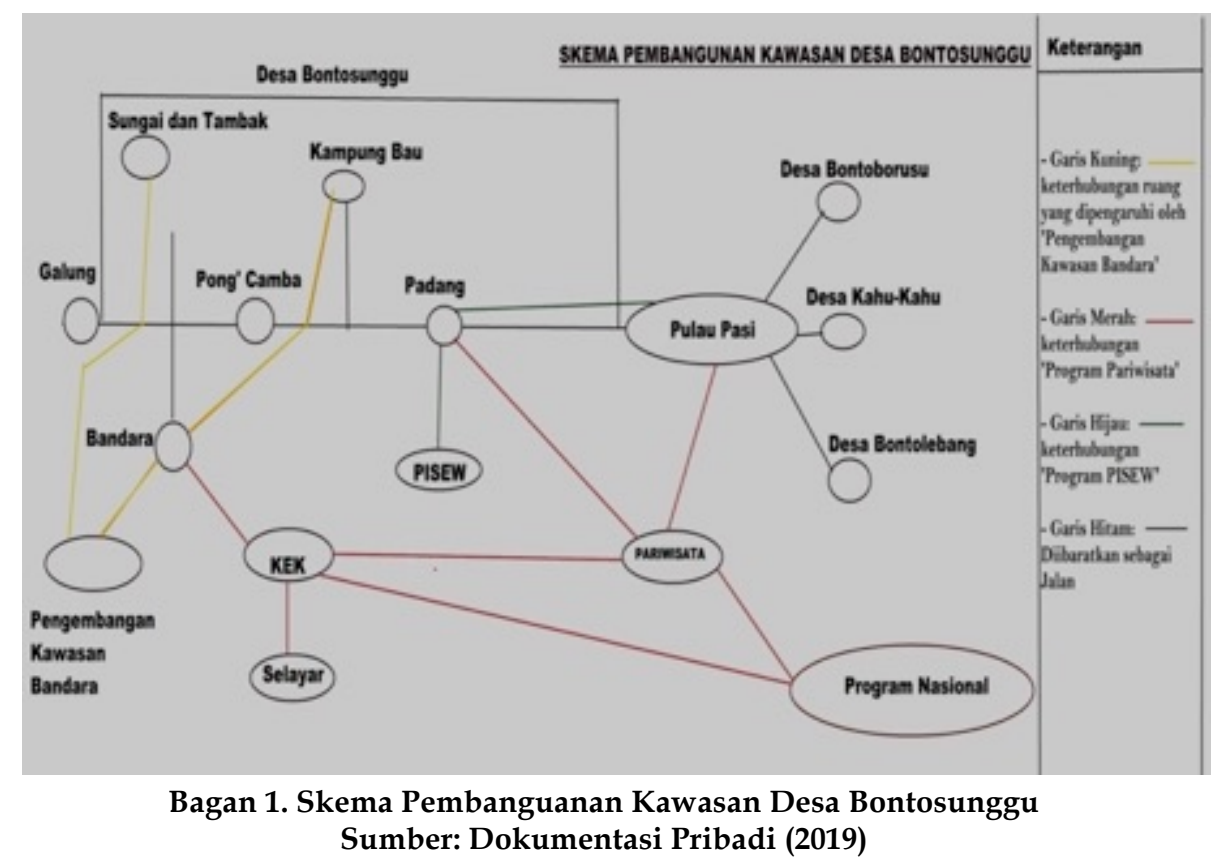

\section{- Kampung Bau: Eksklusi Spasial Di Era Demokratisasi}

Diprioritaskannya perkampungan nelayan Padang sebagai pusat pembangunan kawasan, selain pengembangan area bandara di Bontosunggu, memberi kepedihan dan kegetiran bagi masyarakat yang tinggal di Kampung Bau. Kondisi perkampungan yang muncul akibat pembangunan bandara ini, sangat jauh berbeda dibandingkan dengan perkampungan lain di desa Bontosunggu (lihat Gambar 7). Kegetiran terkait kondisi Kampung Bau dan masyarakat yang tinggal di wilayah tersebut, dikisahkan oleh Ibu Ati, selaku ibu rumah tanggan dan juga merupakan keluarga dari Pak Aslam, sewaktu saya mendatangi rumahnya yang terletak di empat rumah yang ada di perkampuran baru ini bahwa;

Disini susah sekali air. Air untuk minum itu diambil dari Galung, baru dimasak mi. Itu yang ambil air disana orang yang tidak beli air galon. Listrik juga, nyambung di bengkel jaki ini, karena nda adapi masuk tiang listrik sampai disini, kalau ku dengardengar masalah tanah. Tanahnya warga yang tidak mau ditanami listrik. Dulu, ambil air di Camba' jaki, sekarang tidak jalan mi itu air. Pernah juga dulu dijanjiki sama pak desa mau dibangunkan jalanan masuk kesini, tetapi belumpi ada sampai sekarang. bantuan wc juga tidak ada. Beda sekali sama di Padang. Makanya disini rata-rata belum punya pi wc, kita tahumi, kita urusi dulu uang makan baru membangun-bangun kebutuhan yang lain (Ibu Ati, 30 November 2018).

\footnotetext{
${ }^{5}$ Dalam pengetahuan masyarakat setempat, terdapat sebuah pembagian geografis berdasarkan kata 'di luar' dan 'di dalam'. Maksud dari kata 'di luar' artinya merujuk pada perkampungan pesisir, sedangkan kata 'di dalam' merujuk pada perkampungan agraris.
} 


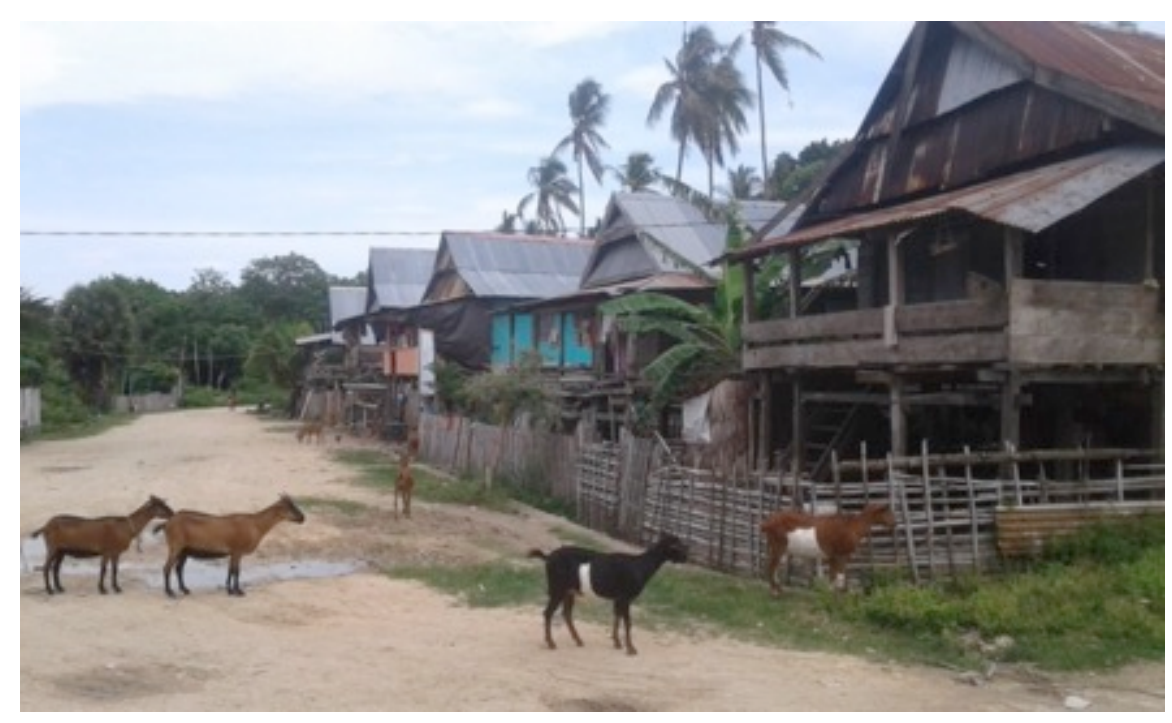

Gambar 7. Potret Pemukiman Kampung Bau Sumber: Dokumentasi Pribadi (2019)

Selain Ibu Ati, penuturan terkait pembangunan desa Bontosunggu yang lebih diprioritaskan di Padang, juga dituturkan oleh Pak Hanafi, selaku ketua BPD, yang bercerita kepada saya soal distribusi pembangunan dan bantuan yang tidak merata di desa bahwa;

Bantuan lebih banyak di Padang, pembangunan juga. Sama itu tempat sampah,pernah ka bilang sama pak desa, kita disini berapa tongji pak desa warganya, apalagi mau lomba desa, bagus tong kalau ada bantuan disini tempat sampah. Tapi pak desa jalan poros ji na perbaiki terus, jadi saya bilang kalau pemilihan sama kerja bakit, tidak usah panggil masyarakat disini pak desa. jadi kasih keluarmi saja kambung bau dari bontosunggu pak desa, berdiiri sendiri saja. Hehe. Jadi warga disini kayak dibuangji, itupi kerja bakti baru rajin dipanggil orang disini. Tapi kalau ada pembagian tidak ada na dapat (Pak Hanafi, 17 Desember 2018).

Sambil menikmati rokoknya dan menyuruh saya untuk menikmati secangkir kopi hangat yang dihidangkan, Pak Hanafi kembali melanjutkan kisahnya, dimana dia melihat Kampung Bau ini sebagai perkampungan yang berada di luar garis dari pembangunan desa. Dengan kalimat candaan, ketua BPD Bontosunggu ini berujar kepada saya;

Jadi nanti itu mau saya suruh tim pemeriksa masuk kesini, arahkan masuk supaya dia lihat kondisi disini, jangan selalu di Padang dilihat haha. Disini itu kayak memangmi dunia lain. Tidak ada sekali ini pak desa, Na kasih diluar garis betul ini kampung bau kasian, ta' jampe' (tidak diperhatikan) betul (Pak Hanafi, 17 Desember 2018).

Penuturan dari Pak Hanafi terkait ketimpangan dan pembangunan yang massif di Padang, ialah dampak dari beberapa logika pembangunan kawasan yang hanya berpijak pada ruang geografis yang memiliki nilai lebih, seperti yang dikonseptualisasikan oleh Smith (2008), seorang pakar ekonomi-politik pembangunan. Dalam risalahnya tersbut, ketimpangan pembangunan menurut 
Smith (2008), cenderung bercorak geografis. Kondisi ini disebabkan oleh adanya eksploitasi alam (ruang) sebagai konsekuensi pergerakan kapital yang mencari ruang atau kawasan yang lebih menguntungkan, space as use value (Smith, 2008; 77).

Direpresentasikannya Padang sebagai pusat pembangunan di desa, bercampur aduk dengan racangan pengembangan kawasan bandara yang terletak di antara dusun Galung dan Bontomanai. Kondisi ini kemudian menggiring masyarakat yang bermukim di perkampungan baru, Kampunng Bau, semakin sulit dan terisolasi. Keadaan Kampung Bau yang semakin terabaikan dari hiruk-pikuk gaung pembangunan di Desa Bontosunggu, diutarakan dengan nada pedih oleh Pak Anto, korban relokasi bandara yang bermukim di Kampung Bau, ketika saya sedang menikmati hidangan malam di pesta pernikahan di desa ini:

Saya di kampung bau tinggal, itu kasian disana, biar listrik belum ada masuk. Sebenarnya itu masalah tanah sudah selesai, tapi pak desa belum kasih masuk listrik. Padahal 12 ji itu listrik na butuhkan untuk masuk disana, apalagi mau jadi jalan poros nanti disana. Sebenarnya itu kekurangannya pak desa, karena kampung bau ini masih bagian dari Bontosunggu, jadi seharusnya tetap diperhatikan juga. Na lama sekali mi itu tidak diperhatikan orang disana, selalu padang ji yang diperhatikan. Kita ini dikampung bau, betul-betul seperti dibuang sama pak desa (Pak Anto, 23 Desember 2018).

Disingkirkan lalu dibuang, ialah dua kata yang merepresentasikan kondisi Kampung Bau. Hidup dengan serba keterbatasan dan tersingkir dari agenda pembangunan, ialah konsekuensi dari logika kawasan yang lebih memilih tempat strategis dan menguntungkan, untuk perputaran modal dan kapital. Dalam kasus Desa Bontosunggu, perputaran dan arus kapital berpusat di kawasan perkampungan nelayan Padang dan kawasan Bandara H. Aeropala.

Tidak hanya jauh dari hiruk-pikuk pembangunan desa, Kampung Bau juga seringkali dicitrakan dan disimbolisasi sebagai tempat 'kumuh' dan 'kampung setan'. Narasi dan simbolisasi ruang yang dilekatkan kepada Kampung Bau, saya temui ketika sedang mengunjungi perkampungan ini di malam hari. Diperjalanan pulang, saya bertemu dengan Pak Dudu dan Pak Sofyan, yang sedang asik menikmati kopinya di depan kios milik Pak Dudu. Secara, tiba-tiba, Pak Dudu bertanya kepada saya, bahwa:

Dari mana?, Oww, Dari kampung bau? Ai kampung kumuh itu. Lama sekalimi itu kampung, dari dibangun bandara tidak ada peningkatan disana, itu kalau ada masuk Malaikat Mikail ke kampung bau, tidak singgah-singgah i, ka persatuannya orang disana tidak bagus. Saya pernah tinggal juga disitu. Itu rumah ku yang na tinggali sekarang anak sama menantu disana. Saya pindahka ke lapangan bangun rumah. Ada yang bilang, bodo-bodonya itu orang kenapa ada rumahnya bagus disana, na malah bangun rumah jellek di lapangan (Pak Dudu, 28 Desember 2018). 
Setelah Pak Dudu berkomentar terkait persoalan Kampung Bau yang dicitrakan sebagai 'kampung kumuh' dan 'tertinggal', Pak Sofyan, yang merupakan sahabat dari Pak Dudu juga ikut memberikan komentar dan berujar, bagaimana Kampung Bau itu dicitrakan sebagai kampung setan, kepada saya bahwa:

Makanya, Malaikat Mikail saja yang pembawa rejeki kalau lewat di Kampung Bau, tidak singgah-singgah, apalagi Kepala Desa yang manusia biasa hehe. Itu pak desa, kalau pergi ke kebunnya disana, tidak pernah singgah, na lewati begituji hahaha. Apalagi didaerab itu ada namanya kampung setan, kalau disini na bilang orang lau ulu, orang yang didapat tinggal kepalanya saja. Jadi tidak ada memang kehidupan disana (Pak Sofyan, 28 Desember 2018).

Penuturan Pak Sofyan dan Pak Dudu, seakan memberi kesan 'ketertinggalan' yang dimistiskan, melalui simbolisasi-simbolisasi kampung setan dan Malaikat pemebawa rejeki yang tidak berkunjung ke kampung ini. Tidak hanya penuturan dari Pak Sofyan dan Pak Dudu yang saya dengar terkait kemistisan yang diproduksi untuk kampung ini. Seorang Ibu rumah tangga bernama Ibu Ita, tinggal di dusun Bontomanai, pernah mengatakan dan kaget mendengar saya pernah mengunjungi kampung tersebut di malam hari: Pernah ke Kampung Bau malam-malam? Beraninya dih, saya saja orang asli sini, tidak berani. Disana itu sudah gelap, ada kuburan, sama pohon-pohon asamnya yang besar-besar baru tuami juga (Ibu Ita, 1 Desember 2018).

Potret material dan mental yang terjelaskan di atas, menggambarkan adanya proses eksklusi spasial yang terjadi di perkampungan baru, Kampung Bau. Meminjam istilah dari Derek Hall, Hirsch, dan Li (2011;7), eksklusi dibaca sebagai 'prevented from benefiting from things', kebalikan dari proses akses sebagai 'the ability to benefit from things'. Proses eksklusi spasial yang terjadi pada Kampung Bau, dipengaruhi oleh dua bentuk 'kuasa' dalam proses eksklusi yakni melalui aturan (regulation) berupa seperangkat aturan yang mengatur terkait program pengembangan pembangunan 'zonasi' kawasan dan legitimasi (legitimation) ${ }^{6}$ Padang sebagai pusat dari desa yang memiliki nilai historis di masa lalu.

Eksklusi spasial Kampung Bau tidak hanya dipengaruhi oleh dua bentuk kuasa, melainkan juga dipengaruhi oleh dua proses yang saling bertautan dengan aktor-aktor yang terlibat di dalamnya (Hall, Hirsch, \& Li, 2011;4-5). Kedua proses tersebut ialah 'pengembangan zonasi kawasan' dan 'demokratisasi pedesaan'. Proses pengembangan zonasi kawasan di Bontosunggu, telah terbahasakan di bagian awal artikel ini dengan tajuk 'politik ruang dan pengembangan kawasan'. Olehnya itu, pada bagian terakhir dari artikel ini, saya akan berusaha untuk menggambarkan bagaimana proses

\footnotetext{
${ }^{6}$ Dalam karya Derek Hall, Philip Hirsch, dan Tania Murray Li, Kuasa Eksklusi terbagi atas empat elemen yang saling mempengaruhi yakni regulasi, paksaan, legitimasi, dan pasar.
} 
demokratisasi pedesaan, yang lebih spesifik membahas terkait soal mekanisme dan proses musrembang di tingkat desa.

Sebagai sebuah saluran politik di tingkat lokal, 'Musyawarah Perencanaan Pembangunan' (Musrembang) Desa juga merekam bagaimana kontestasi ruang yang terjadi di tingkat lokal. Hal ini dikarenakan sebab tiap dusun datang dan mendiskusikan beberapa saran pembangunan di wilayah mereka masingmasing. Kampung Bau yang masuk dalam area Dusun Bontomanai, dalam beberapa kali perencanaan, gagal bersaing dengan beberapa kawasan lain yang ada di desa ini. Hal ini diceritakan oleh kepala Dusun Bontomanai, Pak Budi, ketika saya mengunjungi kios jualannya di jalan poros desa dan bertanya soal pengalamannya mengikuti dan memperjuangkan Kampung Bau, sebagaimana yang diutaran kepada saya bahwa:

Kalau disini pong camba, bangunannya sudah banyak. Tapi kalau di kampung bau, masih banyak sekali mau di bangun. Mushallah juga karena jauh sekali orang dari sana kesini untuk shalat, drainase, jalan setapak, sama wo dan listrik itu penting sekali di kampung bau. Semua usulan di kampung bau, sudah semua mi diusulkan di musrembang, tapi tidak ada pi yang terealisasi (Pak Budi, 13 Januari 2019).

Tersingkirnya perkampungan ini dalam agenda penetapan dan perencanaan prioritas pembangunan desa, melalui sarana musrembang, juga terlihat jelas ketika saya mengikuti musrembang desa di akhir bulan januari. Musrembang desa yang diadakan di gedung pertemuan masyarakat, berlansung ramai (lihat Gambar 8), namun setahu saya hanya dihadiri oleh satu orang dari Kampung Bau, yakni Pak Hanafi, selaku Ketua BPD Bontosunggu, yang dalam kesempatan tersebut tidak berkomentar banyak terkait Kampung Bau. Dalam pertemuan tersebut, beberapa perwakilan instansi maupun dusun, masingmasing mengajukan saran prioritas pembangunan yang harus dilaksanakan di desa.

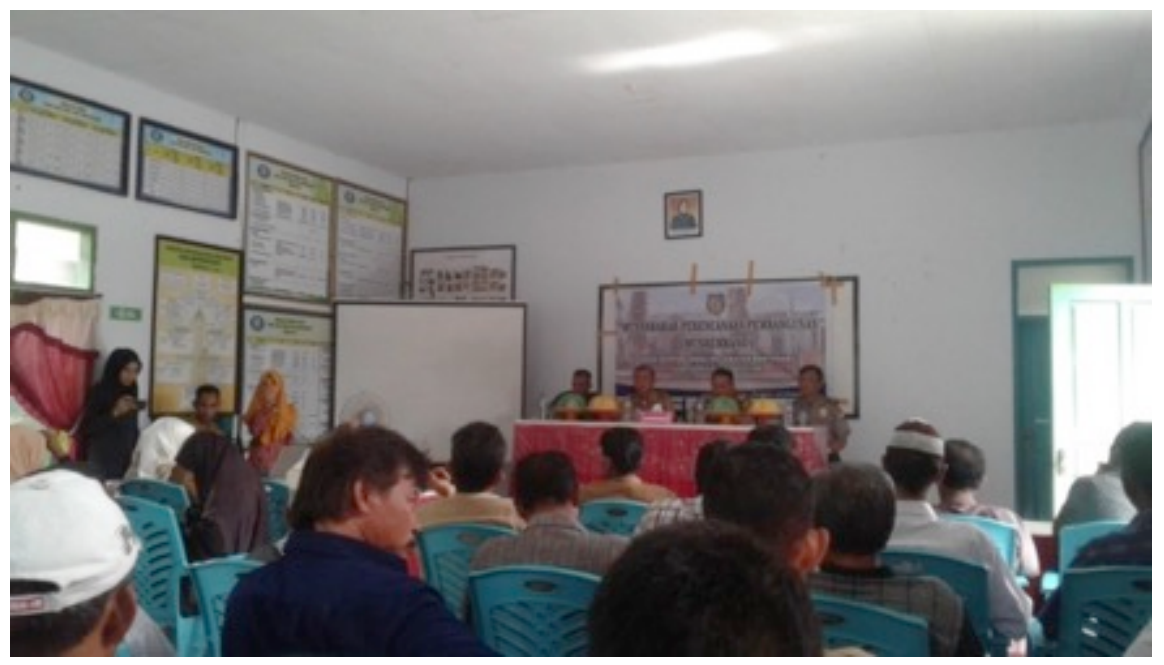

Gambar 8. Suasana Musrembang Desa Bontosunggu Sumber: Dokumentasi Pribadi (2019) 
Ketika tiba giliran dari Pak Budi untuk berkomentar terkait saran pembangunan desa untuk Kampung Bau, dia merekomendasikan hanya lima bantuan pembangunan wc untuk Kampung Bau yang memiliki 22 rumah di kampung tersebut. Hal ini tentunya tidak sebanding dengan kebutuhan dan kondisi material masyarakat yang ada di kampung tersebut, terlebih lagi persoala listrik yang belum ada dan saluran drainase yang juga seharusnya disarankan oleh kepala dusun yang mewakili perkampungan baru ini.

Sehabis rapat musrembang, saya pun lansung bertanya kepada Pak Budi, terkait minimnya program yang dia usulkan untuk Kampung Bau, mengingat inilah wadah yang tepat untuk membicarakan soal pembangunan yang akan dilakukan di tingkat desa. Dengan segera saya pun menghampiri Pak Budi, dan bertanya bahwa:

Saya: kenapa pas tadi diminta untuk bicara soal Kampung Bau, sedikit sekaliji saran yang kita bilang Pak?, tanya saya.

Pak Budi: kalau banyak sekali, capek maki bicara nanti, baru tidak adaji terealisasi seperti tahun-tahun kemarin. Sebenarnya banyak sekali na butuhkan itu Kampung Bau. Yah tapi itumo dulu wc. Sempat tidak jadi ji juga nanti dibangunkan lagi. Lihat mi tadi toh, masih banyak pembangunan mau dilakukan di Padang, yah paling disana ji dulu diprioritaskan. Terakhir-terakhirpi kita disini (Pak Budi, 21 Januari 2019).

\section{Kesimpulan}

Gambaran dari proses demokratisasi desa serta rencana pengembangan program kawasan bandara di Bontosunggu, telah menghimpit masyarakat yang tinggal di Kampung Bau kedalam sebuah dilema pembangunan. Dilema yang kemudian berakibat pada terjadinya eksklusi spasial, melalui dua bentuk kuasa, yakni melalui seperangkat aturan program pengembangan kawasan (KEK, PISEW, dan RTRW Kabupaten Kepulauan Selayar) dan legitimasi sebagai pusat desa yang memiliki nilai historis di masa lalu.

Disatu sisi, kehadiran bandara sebagai salah satu aspek penunjang mobilisasi masyarakat ke berbagai wilayah, namun pada sisi yang lain berdampak pada proses 'De-Peasanisasi' dan 'De-Agranisasi' masyarakat yang berbasis pada aktivitas berkebun. Selain proses pembangunan bandara, pengembangan kawasan yang berpusat di perkampungan nelayan Padang, sebagai pusat desa yang menghubungkan tiga desa yang berada di Pulau Pasi, juga memberi pengaruh besar terkait gerak pembangunan di desa Bontosunggu.

Kedua proses eksklusi spasial yang terjadi di Bontosunggu, bercampur kedalam dua bentuk proses yang berkembang di desa ini, yakni pengembangan pembangunan 'zonasi' kawasan dan demokratisasi desa. Proses-proses tersebut, telah menutup peluang pemerataan pembangunan di tingkat lokal. 
Hal ini dikarenakan, pembanguanan desa dalam proses demokratisasi yang sering digaungkan sebagai program otonomi desa, ternyata tidak dapat terhindar dari berbagai regulasi dan kebijakan di tingkat yang lebih atas (daerah maupun pusat).

Secara keseluruhan, artikel ini tidak memiliki kapasitas untuk 'menghakimi' dan 'menghujat' bahwa pembangunan desa yang massif di Bontosunggu, tidak memiliki dampak yang besar terhadap masyarakat yang bermukim di desa ini. Akan tetapi, artikel ini lebih melihat dan mengurai masalah yang ternyata menghadirkan sebuah dilema pembangunan dibalik kemajuan proses demokratisasi desa yang telah berlansung empat tahun lamanya di Indonesia.

Terakhir, ada beberapa catatan penting yang patut diperhatikan dalam proses demokratisasi kawasan pedesaan di tingkat lokal, dari pengamatan saya di Bontosunggu ialah pertama, narasi tentang otonomi desa melalui undangundang desa nomor 6 tahun 2014, ternyata tidak lepas dari berbagai intervensi aturan dan kebijakan dari tingkat daerah maupun nasional, kedua, otonomi desa mesti berpijak pada re-distrbusi pembangunan pada setiap wilayah di pedesaan, dan ketiga, penting untuk agar regulasi ini menjadi 'daya' sekaligus 'alat' untuk melindungi kawasan pedesaan dari berbagai intervensi pembangunan di tingkat derah maupun pusat, yang dapat berdampak pada terjadinya konflik dan krisis di pedesaan.

\section{Daftar Pustaka}

Benjamin, Rubbers. (2019). Mining towns, enclaves and spaces: A genealogy of worker camps in the Congolese copperbelt.

Cahyono, E. (2017). "Rambu-Rambu Pembangunan Kawasan Pedesaan: Pembelajaran Kasus Pengembangan Kawasan Pariwisata Nasional", dalamZakaria, A (ed.), Potret politik dan Ekonomi Lokal di Indonesia: Dinamika Demokratisasi, Pengembangan Ekonomi, dan Kawasan Pedesaan. Yogyakarta: IRE, 375-413.

Hall, Derek., Hirsch, Philip., Li, Tania Murray. (2011). The Power of Exclusion: Land Dilemmas in Southeast Asia. Singapore: University of Hawai'I Press Honolulu

Purwani, Ofita. (2017). Javanese cosmological layout as a political space. Jurnal Cities 61 (2017) 74-82.

Harvey, David., (2003). The New Imperialism.New York: Oxford University Press.

Neil, Smith. (2008).Uneven Developmen: Nature, Capital, and the Production of Space. USA: The University of Georgia Press. 
Warda., Andersonb., Gilbertzc. (2017). Public stealth and boundary objects: Coping with integrated water resource management and the post-political condition in Montana's portion of the Yellowstone River watershed. Jurnal Geoforum 83 (2017) 1-13.

\section{Dokumen:}

Bappeda. Rancangan Tata Ruang dan Wilayah, Kabupaten Kepulauan Selayar.20122032

Bappeda. 2017. Dokumen Rencana Program Pengembangan Infrastruktur SosialEkonomi Wilayah 2018 